\title{
Microbial Nitrate Reduction in Freshwater Sediments
}

\author{
By J. GWYNFRYN JONES \\ Freshwater Biological Association, The Ferry House, \\ Ambleside, Cumbria LA22 OLP
}

(Received 2 March 1979)

\begin{abstract}
Nitrate reductase activity was three to four orders of magnitude greater in freshwater sediments than in the overlying water. Viable (most probable number) counts of denitrifiers provided sufficient resolution to distinguish between anoxic and surface waters, and between these and sediments, but did not correlate with differences between or within sediment cores. Activity within the sediment depended on the electrode potential $\left(E_{\mathrm{h}}\right)$ profile, which in turn was related to the degree of turbulence and oxygen concentration in the overlying water. Sediments from the littoral zone or those in contact with oxygenated water were oxidizing to a depth of 5 to $10 \mathrm{~mm}$ and the $E_{\mathrm{h}}$ then decreased rapidly. In these sediments nitrate reductase activity was often at its maximum at a depth of 10 to $15 \mathrm{~mm}$, on the $E_{\mathrm{h}}$ gradient, and coincided with a mean $E_{\mathrm{h}}$ value of $210 \mathrm{mV}$. Under reducing conditions the $E_{\mathrm{h}}$ gradient moved upwards and nitrate reductase activity was greatest at the sediment-water interface. These observations were supported by analyses of the nitrogen gas content of the sediments. Inhibition of the enzymes with chlorate indicated that approximately $60 \%$ of the activity was dissimilatory in sediments where the $E_{\mathrm{h}}$ was greater than $+100 \mathrm{mV}$, and that this proportion increased to more than $90 \%$ when the $E_{\mathrm{h}}$ fell below $+50 \mathrm{mV}$. Although the evidence was not conclusive, there was also some indication that nitrate reductase activity in aerobic surface sediments was greater in the larger $(>250 \mu \mathrm{m})$ particle size fraction, which suggested that these particles might act as microsites for nitrate respiration.
\end{abstract}

\section{INTRODUCTION}

The numbers and activity of bacteria in freshwater sediments are three to four orders of magnitude greater than in the overlying water. The sediment is therefore an important site of microbial activity and has received particular attention in studies on denitrification in freshwaters. Field experiments with ${ }^{15} \mathrm{NO}_{3}{ }^{-}$have demonstrated that $63 \%$ of the label was lost through denitrification within $4 \mathrm{~d}$ (Chen et al., 1972) and field measurements have shown $90 \%$ (Tiren et al., 1976) and 95 to $97 \%$ (Kessel, 1977a) conversion of nitrate to $\mathrm{N}_{2}$. The effects of nitrate concentration (Andersen, 1977 $a, b$; Kessel, 1977b, 1978) and temperature (Andersen, 1977 b; Kaplan et al., 1977; Kessel, 1977b) on denitrification have also been investigated. The role of oxygen in denitrification has been the centre of a long standing controversy (Brezonik, 1977; Delwiche \& Bryan, 1976) and its potential controlling effect has therefore been considered in some detail (Kessel, 1977b; Focht \& Verstraete, 1977). Tiren et al. (1976) pointed out that denitrification could occur in sediments even when the overlying water contained 6 to $8 \mathrm{mg} \mathrm{O}_{2} \mathrm{I}^{-1}$. Brezonik (1977) and Focht \& Verstraete (1977) considered anoxic microzones, such as those within particles, as possible sites of denitrification in what appeared to be aerobic sediment.

It would not be possible to discuss the effect of oxygen tension on denitrification without considering the related role of electrode potential $\left(E_{\mathrm{h}}\right)$. Microbial processes are controlled by $E_{\mathrm{h}}$ and the nitrate concentration in a sediment can, in turn, affect this potential. It is 
not surprising, therefore, that the inter-relationship of $E_{\mathrm{h}}$ and denitrifying activity has attracted so much attention. Kessel (1978) concluded that denitrification occurred below the oxidized sediment where the $E_{\mathrm{h}}$ was not greater than $+100 \mathrm{mV}$. This agreed well with the findings of Johnston et al. (1974) who observed an $E_{\mathrm{h}}$ shift from +340 to $+100 \mathrm{mV}$ as oxygen was used up and a poising of the $E_{\mathrm{h}}$ at this lower level as the nitrate was consumed. Graetz et al. (1973) reported that nitrate stabilized the sediment $E_{\mathrm{h}}$ at about +200 to $+100 \mathrm{mV}$. These values for the overall effects of nitrate and denitrification on the sediment are somewhat lower than the values observed in cultures. Focht \& Verstraete (1977), in their review, cite an $E_{\mathrm{h}}$ range of +350 to $+50 \mathrm{mV}$ for nitrite reduction, poising at $+200 \mathrm{mV}$ being apparently due to $\mathrm{N}_{2} \mathrm{O}$.

The methods used to study denitrification in the natural environment have included measurements of changes in nitrate concentration, ${ }^{15} \mathrm{~N}$-labelling (Brezonik \& Lee, 1968), ${ }^{13} \mathrm{~N}$-labelling (Gersberg et al., 1976), gas chromatographic measurement of $\mathrm{N}_{2} \mathrm{O}$ reduction (Garcia, 1974) and acetylene inhibition (Sorensen, 1978a). Measurement of nitrate reductase has been used in marine systems to study denitrification (Packard et al., 1977) and the nitrogen nutrition of phytoplankton (Eppley et al., 1969; Collos \& Slawyk, 1977).

This paper describes the use of a nitrate reductase assay to determine the depth distribution of nitrate reduction in freshwater sediments, and to assess the relative importance of denitrification in relation to the electrode potential of the sediment.

\section{METHODS}

Sampling. Water samples were taken with a Friedinger water bottle and transferred to glass bottles which had been sterilized by dry heat $\left(180^{\circ} \mathrm{C}\right.$ for $\left.1 \mathrm{~h}\right)$. Sediment samples were taken with a Jenkin surface mud corer and sub-sampled on extrusion using the device described by Jones (1976). The sediment samples came from the deepest points of the South Basin of Windermere, Grasmere and Blelham Tarn, under $40 \mathrm{~m}, 21.5 \mathrm{~m}$ and $14.5 \mathrm{~m}$ of water, respectively. Details of other sites used are provided in the text. The lakes are listed in order of increasing eutrophication and consequently of hypolimnetic deoxygenation and sediment reduction. The organic sediments in all three lakes are oxidized at the mud-water interface in spring. The $E_{\mathrm{h}}$ discontinuity layer, or gradient, gradually moves upwards during the summer and actually enters the overlying water in Grasmere and Blelham Tarn.

$E_{\mathrm{h}}$ measurements. The sediment $E_{\mathrm{h}}$ (cell potential plus the potential of the reference electrode) was measured at $1 \mathrm{~mm}$ depth intervals with a bright platinum electrode and a fast-flow calomel reference electrode, using the equipment and procedure described by Jones (1979).

Nitrate reductase assay. The assay was essentially that of Lowe \& Evans (1964) except that methyl viologen (Sigma) was used as electron donor. The incubation mixture contained equal volumes of enzyme extract, substrate solutions and dithionite/bicarbonate solution. The first of these was prepared by sonicating a $10^{-1}$ dilution of sediment in extraction solution at an amplitude of $12 \mu \mathrm{m}$ for $2 \mathrm{~min}$ in an ice bath. The extraction solution contained $1.7 \%(\mathrm{v} / \mathrm{v})$ Triton $\mathrm{X}-100,0.15 \%(\mathrm{w} / \mathrm{v})$ polyvinylpyrrolidone and $75 \mu \mathrm{M}^{-} \mathrm{MgSO}_{4}$ in $0.1 \mathrm{M}$-phosphate buffer, $\mathrm{pH} 7.5$. After sonication the samples were centrifuged at $4000 \mathrm{~g}$ for $15 \mathrm{~min}$ at $0^{\circ} \mathrm{C}$ and the supernatant (enzyme extract) was then removed. All solutions were kept in ice/water baths and all manipulations before incubation were performed at a similar temperature. Incubation was for $1 \mathrm{~h}$ at $35^{\circ} \mathrm{C}$ and after termination the colour was allowed to develop for $10 \mathrm{~min}$ before reading at $540 \mathrm{~nm}$. For chlorate inhibition studies, the substrate solution contained $4.92 \mathrm{~g} \mathrm{KClO}_{3} \mathrm{l}^{-1}$. The reproducibility of the nitrate reductase assay, as applied to freshwater sediments, was tested before detailed studies were started. Variability within a sediment core was low $(95 \%$ confdence limits within $4 \%$ of the mean) but that between cores was considerably larger $(25 \%)$. Use of chlorate inhibitor increased the variability by about $3 \%$ and expression of results on a dry weight rather than a volume basis increased withinand between-core variabilities to 6 and $37 \%$, respectively. Water samples were analysed by concentrating the plankton on to glass-fibre filters (GF/F, Whatman) and then sonicating the filters in extraction buffer as above. Variability under these conditions was usually about $30 \%$. The detection limits for the assay, as defined in Jones \& Simon (1979), were $1.72 \mu \mathrm{g} \mathrm{NO}_{2}-\mathrm{N}^{-1} \mathrm{~h}^{-1}$ for water and $1.70 \mu \mathrm{g} \mathrm{NO}_{2}-\mathrm{N} \mathrm{ml}^{-1} \mathrm{~h}^{-1}$ for sediment. The highest enzyme activity was obtained with phosphate buffer at $\mathrm{pH} 7.5$; increasing the $\mathrm{pH}$ or using Tris/EDTA buffer lowered the yield. Addition of NADH to the substrate solution had no effect but inclusion of dithiothreitol in the extraction solution resulted in greater activity in most samples. Unfortunately, the SH group protective agent could not be used for chlorate inhibition studies due to an unidentified interference. Linearity of reaction rate with enzyme concentration and time (beyond the normal duration of 
the assay) was confirmed, and examination of temperature effects yielded an energy of activation of approximately $60 \mathrm{~kJ} \mathrm{~mol}^{-1}$ with a $Q_{10}$ over the range examined $\left(8^{\circ} \mathrm{C}\right.$ to $\left.35^{\circ} \mathrm{C}\right)$ of $2 \cdot 4$. Glass-fibre filters were chosen to concentrate plankton samples because the membrane filters used successfully for other enzyme studies (Jones \& Simon, 1979) contained too much nitrite and nitrate, even after thorough rinsing. The enzyme yield from polycarbonate membranes was usually lower than that obtained with glass-fibre filters. Tests with sediments of known activity showed that the yield of enzyme was reduced by about $50 \%$ on passage through the glass-fibre. This may have been partly due to passage of bacteria through the pad (nominal pore size $0.7 \mu \mathrm{m}$, median pore size $0.5 \mu \mathrm{m}$; Sheldon, 1972) as well as to damage during filtration. Values for the water column were corrected for this loss.

Electron transport system (ETS) activity. This was used as a general measure of microbial energy-yielding metabolism, and was determined according to the method of Jones \& Simon (1979).

$A T P$. This was measured using the firefly luciferin-luciferase bioluminescence method. Increased sensitivity was obtained by adopting the procedure of Jones \& Simon (1977). Extractions were performed by injecting $0.5 \mathrm{ml}$ of a $5 \times 10^{-3}$ dilution of sediment into actively boiling Tris buffer at $\mathrm{pH} 7 \cdot 8$. Internal standards, in the form of bacterial mixed cultures, were used with every sample.

Direct counts of bacteria. Counts were performed by epifluorescence microscopy on black membrane filters using the procedure of Jones \& Simon (1975). Sediment samples were diluted $10^{-3}$ with membranefiltered water and sonicated at an amplitude of $11 \mu \mathrm{m}$ for $30 \mathrm{~s}$ to break up clumps before staining with acridine orange at a final concentration of $10 \mathrm{mg} \mathrm{l}^{-1}$.

Enumeration of denitrifying bacteria. The most probable number (MPN) of denitrifiers was estimated by preparing a fourfold dilution series of the samples for 12 dilutions with 8 replicates at each dilution. A preliminary dilution of $10^{-3}$ was used for all sediments. The medium of Stanier et al. (1966) was used and the samples were incubated at $15^{\circ} \mathrm{C}$ for $14 \mathrm{~d}$ under aerobic and anaerobic conditions. A drop each of sulphanilamide and naphthyl solutions were added to test for nitrite. Negative samples were reduced with activated cadmium [zinc rods treated with $20 \%(\mathrm{w} / \mathrm{v}) \mathrm{CdSO}_{4}$ solution and activated by stirring in $0 \cdot 23 \mathrm{M}-\mathrm{HCl}$ ]. If the samples remained negative then it was assumed that nitrate had been reduced to ammonia or $\mathrm{N}_{2}$. The dilutions were performed in $8 \times 12$ microtiter dishes (Sterilin) as described by Rowe et al. (1977) except that a fourfold dilution series was used. This was achieved by transferring $50 \mu \mathrm{l}$ samples into wells containing $150 \mu \mathrm{l}$ of medium with 8-channel Titertek piston pipettes (Jencons). The MPN was obtained from the tables of Harris \& Sommers (1968) using the results from six dilutions with, when possible, the third or fourth dilution scoring approximately $80 \%$ positive.

Analysis of sediment gas content. Cores taken with the Jenkin corer at $1 \mathrm{~cm}$ intervals were stoppered with Suba-seals (William Freeman Co., Barnsley) and then brought to the laboratory and placed in a gas-tight glove box along with all the equipment necessary for handling the samples. The box was flushed with helium for $1 \mathrm{~h}$ and sediment samples were then withdrawn into syringes. A volume of degassed distilled water equal to that of the sediment was then drawn into each syringe, followed by 2 vol. helium. The syringe needle was stoppered, the contents shaken violently for $10 \mathrm{~s}$ and then allowed to equilibrate for $1 \mathrm{~h}$. The syringes were then removed from the glove box and the head space was analysed by gas chromatography. A sub-sample was taken via a $5 \mathrm{ml}$ gas-sampling valve and then separated on a $2 \mathrm{~m}$ column of 60 to 85 mesh Molecular Sieve 5A at an oven temperature of $100^{\circ} \mathrm{C}$. The carrier gas was helium flowing at $40 \mathrm{ml} \mathrm{min}^{-1}$ at a pressure of $276 \mathrm{kPa}$ and the thermal conductivity detector was operated at $200^{\circ} \mathrm{C}$.

\section{RESULTS AND DISCUSSION}

Nitrate reductase activity was far greater in the sediment than in the overlying water column. Results from a stratified lake (Grasmere) in midsummer gave values of 0 to $0.36 \mu \mathrm{g}$ $\mathrm{NO}_{2}-\mathrm{N}^{-1} \mathrm{~h}^{-1}$ for the epilimnion, 3.8 to $5.6 \mu \mathrm{g} \mathrm{NO}_{2}-\mathrm{N} \mathrm{l}^{-1} \mathrm{~h}^{-1}$ for the hypolimnion and $20000 \mu \mathrm{g} \mathrm{NO}_{2}-\mathrm{N}^{-1} \mathrm{~h}^{-1}$ for the top $1.5 \mathrm{~cm}$ of sediment. On an area basis these values were equivalent to a summer average of $1.9,18.7$ and $287 \mathrm{mg} \mathrm{NO}_{2}-\mathrm{N} \mathrm{m}^{-2} \mathrm{~h}^{-1}$, respectively, for the $10 \mathrm{~m}$ basin of Grasmere where the samples originated. These and other measures of denitrification in Grasmere showed that the rates were at least an order of magnitude higher than those for nitrification; nitrogen fixation was not observed unless samples were amended with a source of carbon or phosphorus (G. H. Hall \& K. L. Jones, personal communication). MPN estimates of denitrifiers for these samples were $7.0 \times 10^{3}\left(1.9 \times 10^{2}\right), 7.3 \times 10^{3}\left(4.1 \times 10^{4}\right)$ and $5.6 \times 10^{8}\left(1 \cdot 7 \times 10^{9}\right)$ bacteria $\mathrm{ml}^{-1}$, respectively (the values in parentheses were anaerobic counts). Clearly, over this range of values, there was agreement between the measurements of activity and bacterial counts, and the increased activity in the anoxic hypolimnion could be attributed to anaerobic denitrifiers. These results were in good agreement with earlier 


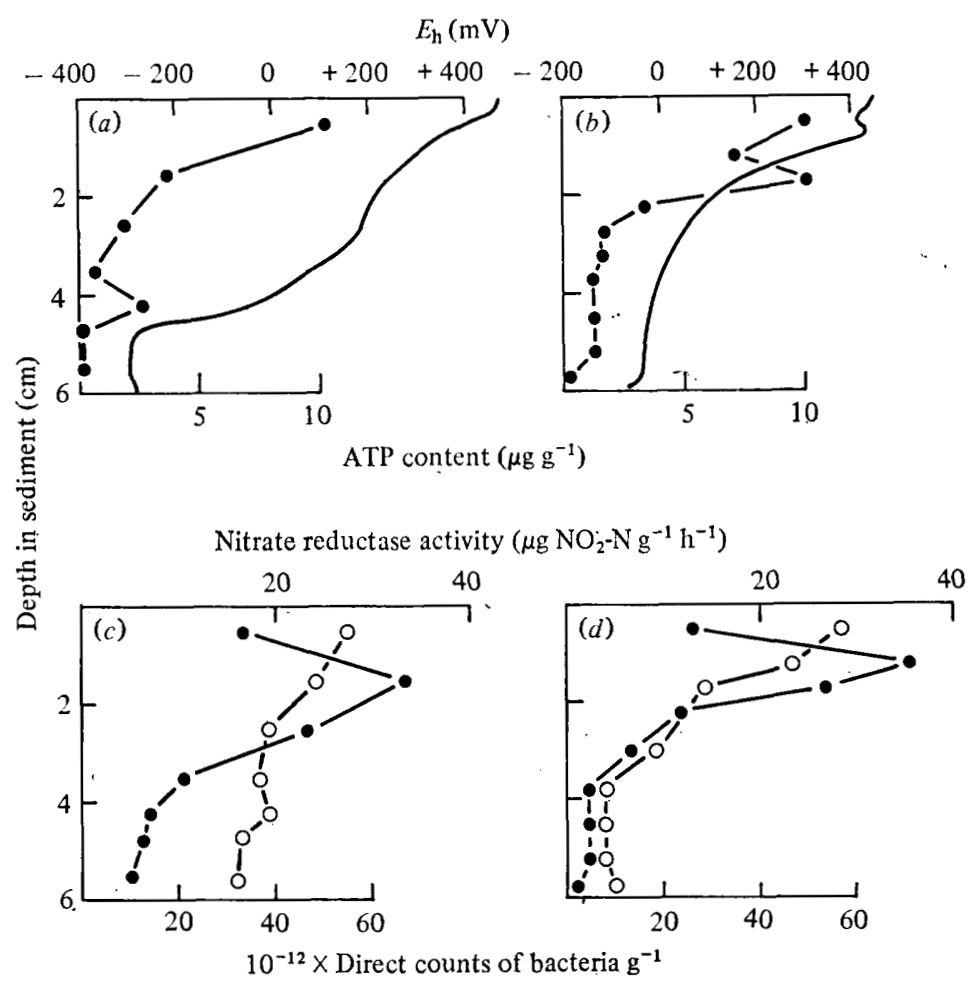

Fig. 1. Analyses of sediments from the littoral $(a, c)$ and the profundal $(b, d)$ zones of the South Basin of Windermere in June 1978. Overlying water depths were $10 \mathrm{~m}$ and $40 \mathrm{~m}$, respectively, and the water was fully oxygenated. $(a, b) E_{\mathrm{h}}$ profile $(-)$ and ATP content $(-) .(c, d)$ Nitrate reductase activity $(O)$ and direct counts of bacteria $(O)$.

work (Jones, 1976; Jones \& Simon, 1979) which showed that microbial activity was three to four orders of magnitude greater in the sediment than in the overlying water column. The activity in the water column was greatest in the anoxic hypolimnion, presumably due to bacterial activity. Similar results were obtained by Packard et al. (1977) who attributed a peak of nitrate reductase activity in deeper marine waters to bacterial denitrification.

When the water overlying the sediment was oxygenated, and conditions were oxidizing at the surface, the sediment nitrate reductase activity was often highest at a depth of several millimetres. This was clearly seen in sediments from the South Basin of Windermere in early summer (Fig. 1). The water in this basin does not become anoxic and the $E_{\mathrm{h}}$ at the sediment surface indicated oxidizing conditions. The peak in nitrate reductase activity was usually between 12 and $15 \mathrm{~mm}$ below the surface. Estimates of microbial biomass (ATP) and direct counts of bacteria did not peak at these depths (Fig. 1), and so the increased nitrate reduction could not be attributed simply to changes in the size of the microbial population. It may, therefore, represent metabolic adaptation to the conditions within the sediment. Clearly, the stratification in nitrate reductase activity required further investigation at a site where a greater variety of sediment conditions could be found. Grasmere is a lake with a relatively shallow mean depth $(7.7 \mathrm{~m})$ but with one basin as deep as $21.5 \mathrm{~m}$. Prevailing winds and development of anoxic conditions at the deepest point ensured that a greater variety of sediment $E_{\mathrm{h}}$ profiles would be obtained (Fig. 2). The two sites ( $5 \mathrm{~m}$ and $16 \mathrm{~m}$ ) at which the $E_{\mathrm{h}}$ gradient (or discontinuity layer) started at some point below the sediment-water interface also had a nitrate reductase peak at depths of 10 to $15 \mathrm{~mm}$. These were comparable to the profiles illustrated in Fig. 1. When conditions were more reducing 


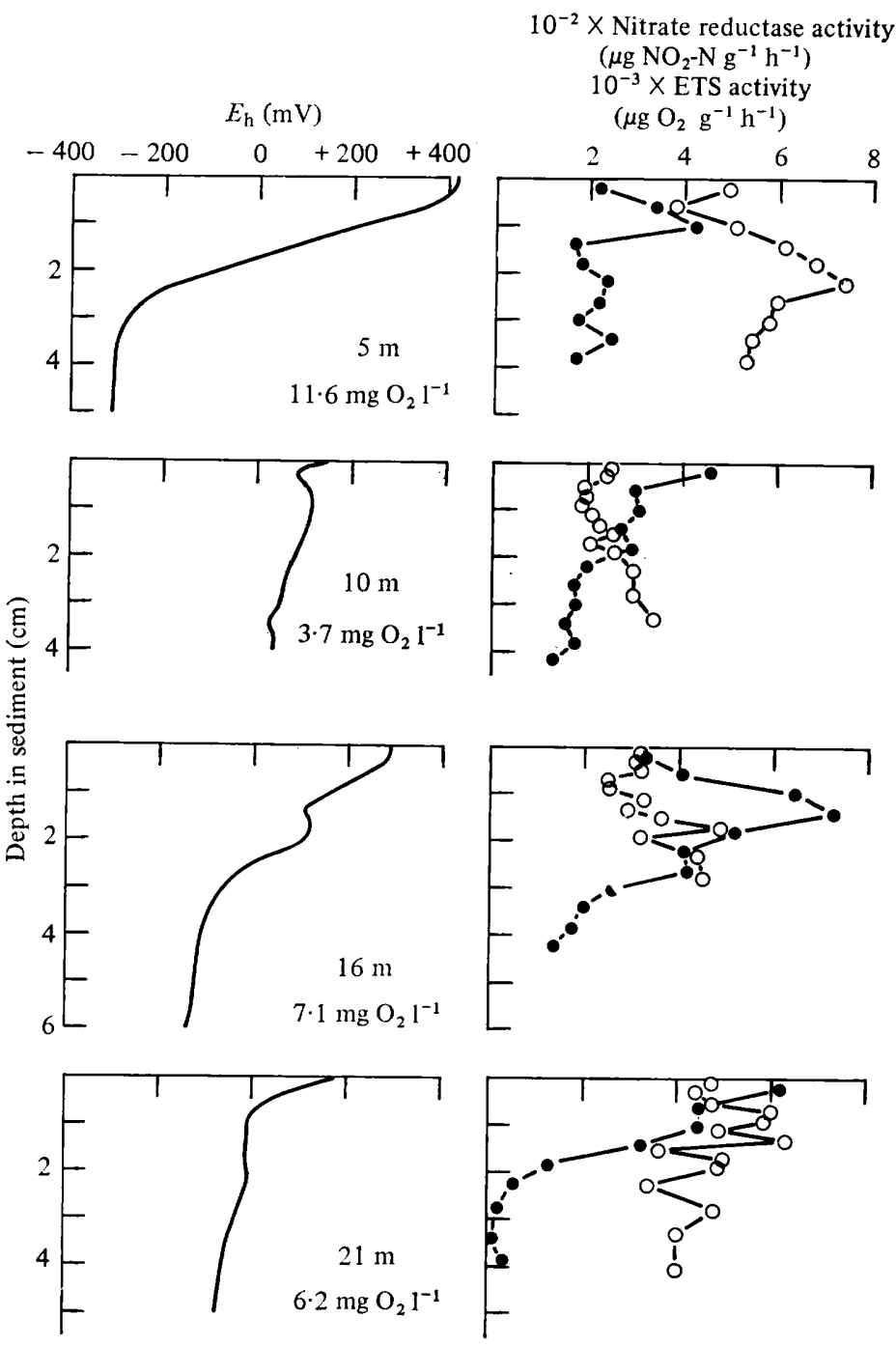

Fig. 2. Analyses of sediments from four sites in Grasmere in May 1978. The depth and dissolved oxygen concentration in the water overlying the sediment are shown. $E_{\mathrm{b}}(-)$, nitrate reductase activity (O) and ETS activity $(O)$.

at the sediment surface (as at the $10 \mathrm{~m}$ and $21 \mathrm{~m}$ sites) and the $E_{\mathrm{h}}$ decreased immediately with depth, the highest nitrate reductase activities were obtained at the sediment surface, being greater at the site $(21 \mathrm{~m})$ with the more pronounced gradient. The nitrate reductase activities did not correspond to any general measure of microbial activity or population density, for example ETS activity, again suggesting that the enzyme activity represented a degree of metabolic adaptation to conditions in the sediment.

The depth of the $E_{\mathrm{h}}$ gradient in a freshwater sediment is controlled to a large degree by the oxygen content and the degree of turbulence in the overlying water, and the reducing power of the sediment (Gorham, 1958). Thus, sediments from the littoral zone have a deeper oxidized layer and the $E_{\mathrm{h}}$ gradient is not as steep as that in profundal muds. Sub-surface peaks of denitrification have been observed in marine sediment by Sorensen $(1978 b)$ using the acetylene inhibition technique; however, $E_{\mathrm{h}}$ measurements were not made. These results conform with the conventional view of a sediment in which aerobic respiration occurs at 


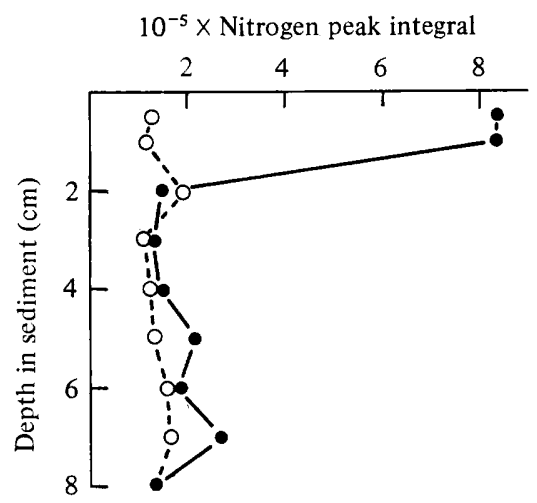

Fig. 3. Gas chromatographic analysis of the depth distribution of nitrogen gas in profundal sediments from Blelham Tarn, sampled in April $1978(\bigcirc)$ at the onset of thermal stratification, and in August 1978 (๑) when the hypolimnion was anoxic.

Table 1. Depth distribution of denitrifying bacteria at four sites in Grasmere (corresponding to those illustrated in Fig. 2) in May 1978

\begin{tabular}{|c|c|c|c|c|c|}
\hline \multirow[b]{3}{*}{ Incubation conditions } & \multirow{3}{*}{$\begin{array}{l}\text { Depth in } \\
\text { sediment } \\
\quad(\mathrm{cm})\end{array}$} & \multicolumn{4}{|c|}{$10^{-9} \times$ Most Probable Number* $\mathrm{g}^{-1}$} \\
\hline & & \multicolumn{4}{|c|}{ Depth of water above sediment (m) } \\
\hline & & 5 & 10 & 16 & 21 \\
\hline Aerobic & $\begin{array}{l}0-1 \\
1-2 \\
2-3 \\
3-4 \\
4-5\end{array}$ & $\begin{array}{r}7 \cdot 4 \\
8 \cdot 3 \\
9 \cdot 7 \\
5 \cdot 7 \\
12 \cdot 1\end{array}$ & $\begin{array}{r}6 \cdot 3 \\
28 \cdot 1 \\
9 \cdot 7 \\
16 \cdot 6 \\
18 \cdot 9\end{array}$ & $\begin{array}{l}7 \cdot 6 \\
5 \cdot 8 \\
4 \cdot 8 \\
3 \cdot 0 \\
1 \cdot 2\end{array}$ & $\begin{array}{r}6.9 \\
19 \cdot 3 \\
10.6 \\
12.5 \\
7.9\end{array}$ \\
\hline Anaerobic & $\begin{array}{l}0-1 \\
1-2 \\
2-3 \\
3-4 \\
4-5\end{array}$ & $\begin{array}{r}17 \cdot 9 \\
18 \cdot 3 \\
16 \cdot 4 \\
7 \cdot 8 \\
10 \cdot 7\end{array}$ & $\begin{array}{r}18 \cdot 6 \\
7 \cdot 4 \\
7 \cdot 5 \\
2 \cdot 3 \\
14 \cdot 5\end{array}$ & $\begin{array}{r}38.6 \\
31.4 \\
4.6 \\
0.9 \\
13.8\end{array}$ & $\begin{array}{r}42 \cdot 2 \\
40 \cdot 3 \\
8.9 \\
21 \cdot 6 \\
11 \cdot 3\end{array}$ \\
\hline
\end{tabular}

* The standard error on $\log$ MPN $=0.15$ and $95 \%$ confidence limits $= \pm 0 \cdot 304$. Results are significantly different when $\left(\log \mathrm{MPN}_{1} / 0 \cdot 2128\right)-\left(\log \mathrm{MPN}_{2} / 0 \cdot 2128\right)>2 \cdot 0$.

the surface. With increasing depth below the surface there are zones of denitrification, sulphate reduction and methanogenesis (Fenchel \& Jørgensen, 1977). As conditions become more reducing, the $E_{\mathrm{h}}$ gradient and the point of maximum nitrate reductase activity move up to the sediment surface. Similar seasonal changes in sulphate reduction have been observed by Jørgensen (1977) in marine sediments. Thus, the zones of certain anaerobic respirations become compressed as anoxic conditions develop. Analyses for nitrogen gas in the sediments (Fig. 3) confirmed this trend of upward movement of nitrate reduction, and thus nitrogen accumulation, as anoxic conditions developed. Greater quantities of gas were also observed in the absence of oxygen.

While the sediment was oxidized at the surface the peak of nitrate reductase activity was observed (Fig. 2) at a mean $E_{\mathrm{h}}$ of $+210 \mathrm{mV}$ (S.D. $70 \mathrm{mV}$ ). This is, of course, lower than the redox potential for the $\mathrm{NO}_{3}^{-} / \mathrm{NO}_{2}^{-}$couple $(+420 \mathrm{mV})$ and slightly higher than the $E_{\mathrm{h}}$ at which denitrification and nitrate poising of sediments was reported by Kessel (1978), Johnston et al. (1974) and Graetz et al. (1973), although nitrite reduction has been reported in cultures by Focht $\&$ Verstraete (1977) over the range +350 to $+50 \mathrm{mV}$. Mortimer (1941, 1942) also considered that an $E_{\mathrm{h}}$ of $+200 \mathrm{mV}$ represented the boundary between oxidizing and reducing conditions.

The numbers of denitrifying bacteria, as estimated by a viable count (MPN) technique, did not correlate in any way with the observed distribution of nitrate reductase activity. The 

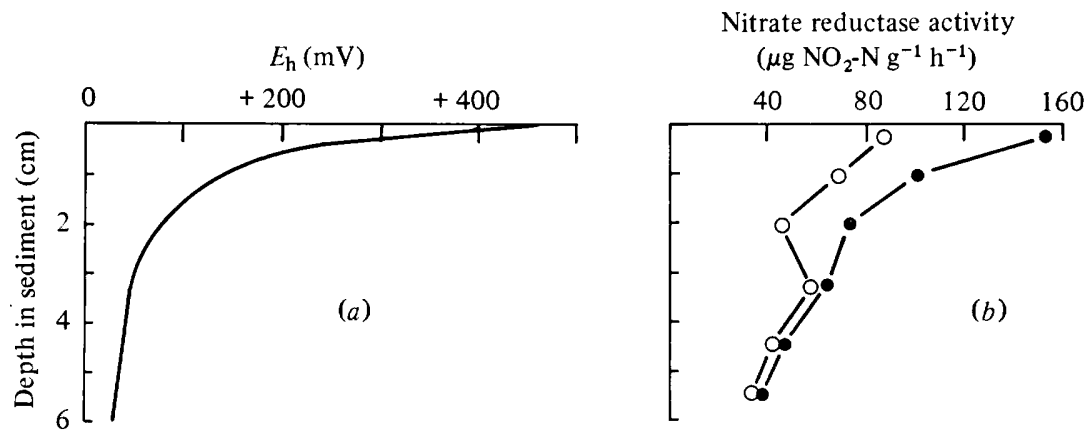

Fig. 4. Analyses of a sediment core from the $21 \mathrm{~m}$ site of Grasmere when the oxygen concentration in the overlying water was less than $1 \mathrm{mg} \mathrm{l}^{-1}$. (a) $E_{\mathrm{h}}$ profile. (b) Nitrate reductase activity in the presence $(O)$ and absence $(O)$ of chlorate inhibitor $\left(4 \cdot 92 \mathrm{~g} \mathrm{KClO}_{3} \mathrm{1}^{-1}\right)$ in the substrate solution.

peaks of enzyme activity at 10 to $15 \mathrm{~mm}$ at the $5 \mathrm{~m}$ and $16 \mathrm{~m}$ sites (Fig. 2) were not reflected in the counts obtained (Table 1), nor were the differences between the sites. Anaerobic counts were, as might be expected, higher than aerobic estimates. The standard error of $\log$ MPN is given by $0.55 \sqrt{ }(\log a / n)$, where $a$ is the dilution ratio (4) and $n$ is the number of replicates at each dilution (8). The count at 1 to $2 \mathrm{~cm}$ depth at the $10 \mathrm{~m}$ and $21 \mathrm{~m}$ sites was significantly different from those at 0 to $1 \mathrm{~cm}$, but only at the $10 \mathrm{~m}$ site was it also significantly different from the 2 to $3 \mathrm{~cm}$ count. The results of these tests are included merely to provide some indication of the variability of the MPN data even with a relatively low dilution ratio and high degree of replication. The medium used for the MPN procedure gave higher counts of bacteria than that of Focht \& Joseph (1973), and the estimates obtained were considerably higher than those of Johnston et al. (1974) and May (1976) from similar freshwater sites. The absence of correlation with nitrate reductase activities within and between sediments may reflect the inadequacy of a viable count procedure for such a study, or the differences in activity may be due, in part, to organisms other than bacteria.

The nitrate reductase assay used in this investigation measured both the assimilatory and dissimilatory enzymes, yet only the latter would be of interest with regard to denitrification processes. The assimilatory enzyme is inhibited by chlorate ions, and the results of some inhibitor studies on a sediment with a steep $E_{\mathrm{h}}$ gradient are shown in Fig. 4. A greater proportion of the enzyme activity was inhibited at the sediment surface where assimilatory processes might be expected to be more important. Approximately $60 \%$ of the total activity was dissimilatory in samples where the $E_{\mathrm{h}}$ was $>+100 \mathrm{mV}$. Between +100 and $+50 \mathrm{mV}$ the dissimilatory portion increased rapidly to about $90 \%$. One might conclude, therefore, that although the enzyme assay demonstrated the region of maximum nitrate reduction in a sediment, a significant proportion of this activity may be linked to assimilatory processes, although such an interpretation of chlorate inhibition should, perhaps, be forwarded with caution (Stouthamer, 1976). There was, however, some additional information which supported the view that the chlorate inhibitor studies provided a fairly accurate estimate of assimilation and dissimilation. At the site where these studies were performed, gas traps had been installed to measure loss of gaseous nitrogen from the profundal zone. At the same time, changes in nitrate concentrations in the overlying water were measured. The total loss of gaseous nitrogen, on an area basis, was equivalent to $54 \%$ of the nitrate-nitrogen removed from the water column. This was in good agreement with the estimate of $60 \%$ dissimilatory nitrate reductase in the surface sediment. The role of the dissimilatory enzymes in the deeper sediments, particularly the formation of ammonia rather than $\mathrm{N}_{2}$ as endproduct (Sorensen, 1978 a) deserves further attention.

An examination of the micro-zonation of enzymic activity in aerobic sediments produced results which were less conclusive (Table 2). Particles from an aerobic sediment were 
Table 2. Effect of sediment particle size on microbial biomass and metabolic activity in aerobic surface sediments from the South Basin of Windermere

$\begin{array}{lccc}\text { Particle size range }(\mu \mathrm{m}) & \text { B } & \begin{array}{c}\text { Ratio } \\ \text { (B/A) }\end{array} \\ \text { Nitrate reductase }\left(\mathrm{mg} \mathrm{NO}_{\mathrm{s}^{-}} \mathrm{N} \mathrm{g}^{-1} \mathrm{~h}^{-1}\right) & 45-125 & 250-500 & 58 \\ \text { ETS activity }\left(\mathrm{mg} \mathrm{O}_{2} \mathrm{~g}^{-1} \mathrm{~h}^{-1}\right) & 0.66 & 38.43 & 81 \\ \text { ATP content }\left(\mu \mathrm{g} \mathrm{g}^{-1}\right) & 0.14 & 11.69 & 4.7\end{array}$

separated into two size classes by a graded wet sieve procedure. Biomass, nitrate reductase and ETS activity were higher in the 250 to $500 \mu \mathrm{m}$ particles than in the 45 to $125 \mu \mathrm{m}$ size range but the ratio of metabolic activity between large and small particle sizes was far greater than it was for biomass. Clear-cut results such as these were not always obtained but they were sufficiently frequent to suggest that large sediment particles with internal $E_{\mathbf{h}}$ gradients might provide conditions conducive to energy metabolism (Jones, 1979), particularly anaerobic respiration. Jørgensen (1977) has already demonstrated that sediment particles can act as micro-niches for sulphate reduction in aerobic sediments. The results for nitrate reductase were not as conclusive, but suggested that microsites of anaerobic respiration could contribute to the nitrate reductase activity of aerobic surface sediments.

I wish to thank J. S. Collis, S. Ellis and S. Irwin for their excellent technical assistance and Mr T. I. Furnass for drawing the figures. Part of this work was commissioned by the Department of the Environment under project number DGR/480/32 and the EEC Environmental Research Programme under contract number 278-77-1 ENV-UK.

\section{REFERENCES}

ANDERSEN, J. M. (1977a). Importance of the denitrification process for the rate of degradation of organic matter in lake sediments. In Interactions Between Sediments and Fresh Water, pp. 357-362. Edited by H. L. Golterman. The Hague: Dr W. Junk.

ANDERSEN, J. M. (1977b). Rates of denitrification of undisturbed sediment from six lakes as a function of nitrate concentration, oxygen and temperature. Archiv für Hydrobiologie 80, 147-159.

BrezonIK, P. L. (1977). Denitrification in natural waters. Progress in Water Technology 8, 373-392.

BrezoniK, P. L. \& LeE, G. F. (1968). Denitrification as a sink in Lake Mendota. Environmental Science and Technology 2, 120-125.

Chen, R. L., Keeney, D. R., Graetz, D. A. \& Holding, A. J. (1972). Denitrification and nitrate reduction in Wisconsin lake sediments. Journal of Environmental Quality 1, 158-163.

Collos, Y. \& SlawYK, G. (1977). Nitrate reductase activity as a function of in situ nitrate uptake and environmental factors of euphotic zone profiles. Journal of Experimental Marine Biology and Ecology 29, 119-130.

Delwiche, C. C. \& Bryan, A. B. (1976). Denitrification. Annual Review of Microbiology 30, 241262.

EpPley, R. W., Coatsworth, J. L. \& Solorzano, L. (1969). Studies of nitrate reductase in marine phytoplankton. Limnology and Oceanography 14, 194-205.
Fenchel, T. M. \& JøRGensen, B. B. (1977). Detritus food chains of aquatic ecosystems: the role of bacteria. Advances in Microbial Ecology 1, 1-58.

Fochr, D. D. \& JoSEPH, H. (1973). An improved method for the enumeration of denitrifying bacteria. Proceedings of the Soil Science Society of America 37, 698-699.

Focht, D. D. \& Verstraete, W. (1977). Biochemical ecology of nitrification and denitrification. $A d$ vances in Microbial Ecology 1, 135-214.

GarcIA, J. L. (1974). Réduction de l'oxyde nitreux dans les sols de rizières du Sénégal: mesure de l'activité denitrifiante. Soil Biology and Biochemistry 6, 79-84.

Gersberg, R., Krohn, K., Peek, N. \& Goldberg, C. R. (1976). Denitrification studies with ${ }^{13} \mathrm{~N}$ labelled nitrate. Science 192, 1229-1231.

Gorham, E. (1958). Observations on the formation and breakdown of the oxidized microzone at the mud surface in lakes. Limnology and Oceanography 3, 291-298.

Graetz, D. A., KeEney, D. R. \& Aspiras, R. B. (1973). Eh status of lake sediment-water systems in relation to nitrogen transformations. Limnology and Oceanography 18, 908-917.

HARRIS, R. F. \& SOMMERS, L. E. (1968). Platedilution frequency technique for assay of microbial ecology. Applied Microbiology 16, 330-334.

Johnston, D. W., Holding, A. J. \& MCCluskie, J. E. (1974). Preliminary comparative studies on denitrification and methane production in Loch 
Leven, Kinross and other freshwater lakes. Proceedings of the Royal Society of Edinburgh B74, 123-133.

JONES, J. G. (1976). The microbiology and decomposition of seston in open water and experimental enclosures in a productive lake. Journal of Ecology 64, 241-278.

JONES, J. G. (1979). Microbial activity in lake sediments with particular reference to electrode potential gradients. Journal of General Microbiology 115, 19-26.

JoNES, J. G. \& Simon, B. M. (1975). An investigation of errors in direct counts of aquatic bacteria by epifluorescence microscopy, with reference to a new method for dyeing membrane filters. Journal of Applied Bacteriology 39, 317-329.

Jones, J. G. \& Simon, B. M. (1977). Increased sensitivity in the measurement of ATP in freshwater samples with a comment on the adverse effect of membrane filtration. Freshwater Biology 7, 253-260.

Jones, J. G. \& Simon, B. M. (1979). The measurement of electron transport system activity in freshwater benthic and planktonic samples. Journal of Applied Bacteriology 46, 305-315.

JøRGENSEN, B. B. (1977). Bacterial sulfate reduction within reduced micro-niches of oxidized marine sediments. Marine Biology 41, 7-17.

Kaplan, W. A., Teal, J. M. \& Valiela, I. (1977). Dentrification in salt marsh sediments: evidence for seasonal temperature selection among populations of denitrifiers. Microbial Ecology 3, 193204.

Kessel, J. F. (1977a). The immobilization of nitrogen in a water-sediment system by denitrifying bacteria as a result of nitrate respiration. Progress in Water Technology 8, 155-160.

KeSSEL, J. F. (1977b). Factors affecting the denitrification rate in two water-sediment systems. Water Research 11, 259-267.

KesSEL, J. F. (1978). The relation between redox potential and denitrification in a water-sediment system. Water Research 12, 285-290.
Lowe, R. H. \& Evans, H. J. (1964). Preparation and some properties of a soluble nitrate reductase from Rhizobium japonicum. Biochimica et biophysica acta 85, 377-389.

MAY, E. (1976). Studies of denitrification in some Scottish freshwater lochs. Ph.D. thesis, University of Dundee.

Mortimer, C. H. (1941). The exchange of dissolved substances between mud and water in lakes. I and II. Journal of Ecology 29, 280-329.

MORTIMER, C. H. (1942). The exchange of dissolved substances between mud and water in lakes. III and IV. Journal of Ecology 30, 147-201.

Packard, T. T., Dugdale, R. C., Goering, J. J. \& BARBER, R. T. (1977). Nitrate reductase activity in the subsurface waters of the Peru Current. Journal of Marine Research 36, 59-76.

Rowe, R., TODD, R. \& WAIDE, J. (1977). Microtechnique for most-probable-number analysis. Applied and Environmental Microbiology 33, 675680.

SHELdon, R. W. (1972). Size separation of marine seston by membrane and glass-filters. Limnology and Oceanography 17, 494-499.

SORENSEN, J. (1978a). Capacity for denitrification and reduction of nitrate to ammonia in a coastal marine sediment. Applied and Environmental Microbiology 35, 301-305.

SORENSEN, J. (1978b). Denitrification rates in marine sediment as measured by the acetylene inhibition technique. Applied and Environmental Microbiology 36, 139-143.

Stanier, R. Y., Palleroni, J. J. \& Doudoroff, M. (1966). The aerobic pseudomonads: a taxonomic study. Jourr.al of General Microbiology 43, 159-271.

Stouthamer, A. H. (1976). Biochemistry and genetics of nitrate reductase in bacteria. Advances in Microbial Physiology 14, 315-375.

TIREN, T., THORIN, J. \& Nommik, H. (1976). Denitrification measurements in lakes. Acta agriculturae scandinavica 26, 175-184. 